\title{
THE DIVERSITY OF SULFUR-OXIDIZING BACTERIAL POPULATIONS AT AN IRANIAN COPPER MINE AND THE SURROUNDING AGRICULTURAL SOILS
}

\author{
SADEGHI Pour MARVI, M. ${ }^{1}$ - POURBABAeE, A. A. ${ }^{1 *}$ - AlikHANI, H. A. ${ }^{1}-$ HAIDARI, A. ${ }^{1}-$ \\ MANAFI, Z. ${ }^{2}$ \\ ${ }^{I}$ Department of soil sciences, College of Agriculture and Natural Resources, University of \\ Tehran. Karaj, Iran. \\ ${ }^{2}$ Research and development office, Sarcheshmeh Copper Complex, National Iranian Copper \\ Industries Co. Rafsanjan, Iran. \\ *Corresponding author \\ e-mail: pourbabaei@ut.ac.ir; phone: +98-26-32231787 (internal 227); fax: +98-26-32231787 \\ (Received $31^{\text {st }}$ Jan 2016; accepted $27^{\text {th }}$ Apr 2016)
}

\begin{abstract}
Sulphur-oxidizing bacteria (SOB) are one of the most important metabolic types of bacteria living in very different soil environments. Mine environments with high concentrations of metals and extreme conditions have led to habitat-specific genera and operational taxonomic units (OTUs) of bacteria. In this study, we compared the diversity of SOB and non-SOB at the Sarcheshmeh Copper Mine Complex (Iran) with the surrounding agricultural soil. Thirty-six mine and agricultural sites were sampled aseptically and assessed by culture-dependent (full-length 16S rRNA cloning) and independent (Denaturing Gradient Gel Electrophoresis (DGGE)) approaches. Results indicated that soil samples from the copper mine region contained diverse OTUs affiliated with of SOB genera including Acidithiobacillus $s p$. and Sulfobacillus sp. and non-SOB including Pseudomonas sp., Bacillus sp., Sphingobium sp., Sphingomonas sp., Acinetobacter sp., Halospirulina sp., and Propionibacterium sp. In addition, the soil samples from the surrounding agricultural sites contained representatives of SOB genera as Thiobacillus sp., Starkeya sp. and non-SOB as Pseudomonas sp., Acinetobacter sp., Bacillus sp., Sphingobium sp., Streptomyces sp., and Propionibacterium sp. These bacterial communities were significantly affected by sulphur in the mine area, and by $\mathrm{pH}$ and calcium concentrations in the agricultural soils.
\end{abstract}

Keywords: Acidithiobacillus, Thiobacillus, bacterial diversity

Abbreviations: $S O B$, sulphur-oxidizing bacteria; OTU, operational taxonomic unit; DGGE, Denaturing Gradient Gel Electrophoresis; ANOSIM, analysis of similarities; N-MDS, non-metric multidimensional scaling; UPGMA, un-weighted pair group method with arithmetic mean; AT, Acidithiobacillus; Th, Thiobacillus; AC, Acinetobacter.

\section{Introduction}

Sulphur-oxidizing bacteria (SOB) are one of the metabolic types of bacteria, which, according to environmental conditions, could be classified into the following groups: mesophilic, thermophilic, acidophilic, neutrophilic, alkalophilic, autotrophic, chemolithotrophic, and heterotrophic (Friedrich et al., 2001; Kelly and Wood, 2000). SOB use sulphur and its ionic derivatives (e.g. thiosulfate) as an electron donor for energy requirements. Most SOB are investigated for their importance in biology, agriculture, economics, and other scientific fields. Heterotrophic SOB could degrade toxic organic matter and play an important role in detoxifying their environments (Johnson, 2008). In addition, soil SOB increase the availability of sulphate $\left(\mathrm{SO}_{4}{ }^{-2}\right)$ for plant absorption and improve plant growth and agricultural production (Smith et al., 2000). SOB belong to different genera as Thiobacillus, Thiospherea, Thiomicrospira, 
Thiospira, Acidiphilum, Thiobacterium, Macromonas, and Acidiphilum. Thiobacilluslike are the most important and frequently occurring SOB, and Kelly and Wood (2000) have classified them into three genera: Acidithiobacillus, Thermithiobacillus, and Hallothiobacillus (Kelly and Wood, 2000).

The bacterial diversity and its dynamism in soil environments have a direct relationship with soil characteristics, i.e. kind of minerals, organic materials, water content, heavy metals, salinity, and $\mathrm{pH}$ (Rodrigues et al., 2014). In most geographical regions with mining activities, high concentrations of sulphur and its subsequent chemical reactions cause decreasing $\mathrm{pH}$ levels into acidic conditions, limiting the colonization of bacterial communities, and imposed selection pressure on specific bacterial populations, such as SOB. SOB present in these mines are considered extremophiles, and account with different species of genera as Acidiphilum sp., Leptospirillium sp. (Robertson and Kuenen, 2006), Acidocella sp., Acidithiobacillus sp. (Johnson, 2008), Ferroplasma sp., Sulfobacillus sp. (Johnson, 2008), Ferrimicrobium sp., Ferribacter sp. (Havlin et al., 2005), Thiobacillus sp., and Hallothiobacillus sp. (Brito et al., 2013). Halophilic SOB species that belong to Hallothiobacillus sp. and Thiomicrospira $s p$. were found in soils with high salinity concentrations (Sorokin et al., 2006). Soils with high concentrations of chromium heavy metal have shown a colonization of Thiobacillus SOB (Brito et al., 2013). In addition, some indirect factors, such as mine topography characteristics (e.g. slope, direction, and soil texture), affect soil properties and subsequent SOB diversity. A copper mine environment with a slope has indicated specific genera of Acidobacteria, Chloroflexi, Firmicutes, and Gammaproteobacteria, which correspond to their differences in soil organic matter and water percentage (Rodrigues et al., 2014).

Mine by-product processing, transportation, drainage, and tailings could alter the property of surrounding soils with different applications, i.e. agriculture and forestry (Castilla and Nealler, 1978; Mendez et al., 2008; Ying et al., 2008; Yun-Guo et al., 2006).

The Iranian copper mine complex of Sarcheshmeh is one of the largest open-cast copper mines in the world and it is located in a region with a high density of pistachio cultivation. Copper mining has been performed through conventional pyrometallurgy and hydrometallurgy with sulphide minerals. Mechanical and biochemical manipulation and processing of minerals has resulted in a large quantity of dust and polluted drainage and tailings that could alter the surrounding environment, and, hence, the soil properties and bacterial populations. No previous studies have investigated the effect of the Sarcheshmeh copper mine on the surrounding soil SOB diversity and frequency. Therefore, in this study we used both culture-dependent and- independent methods of isolate 16S rRNA sequencing and Denaturing Gradient Gel Electrophoresis (DGGE), respectively, to compare the diversity of SOB present in soil samples from the copper mine and the adjacent agricultural soils.

\section{Material and methods}

\section{Samples}

Sampling was performed on two kinds of soil: 22 soil samples from the copper mine region (Sarcheshmeh Copper Mine Complex, Kerman, Iran) and 14 soil samples from the surrounding agricultural areas, as shown in Figure 1. The sampling region had a mean annual temperature of $25^{\circ} \mathrm{C}$, rainfall of $160 \mathrm{~mm}$, and a clay-loam soil texture. The 
soils were classified as Typic Haplosalids according to soil taxonomy (Soil Survey Staff, 2010).

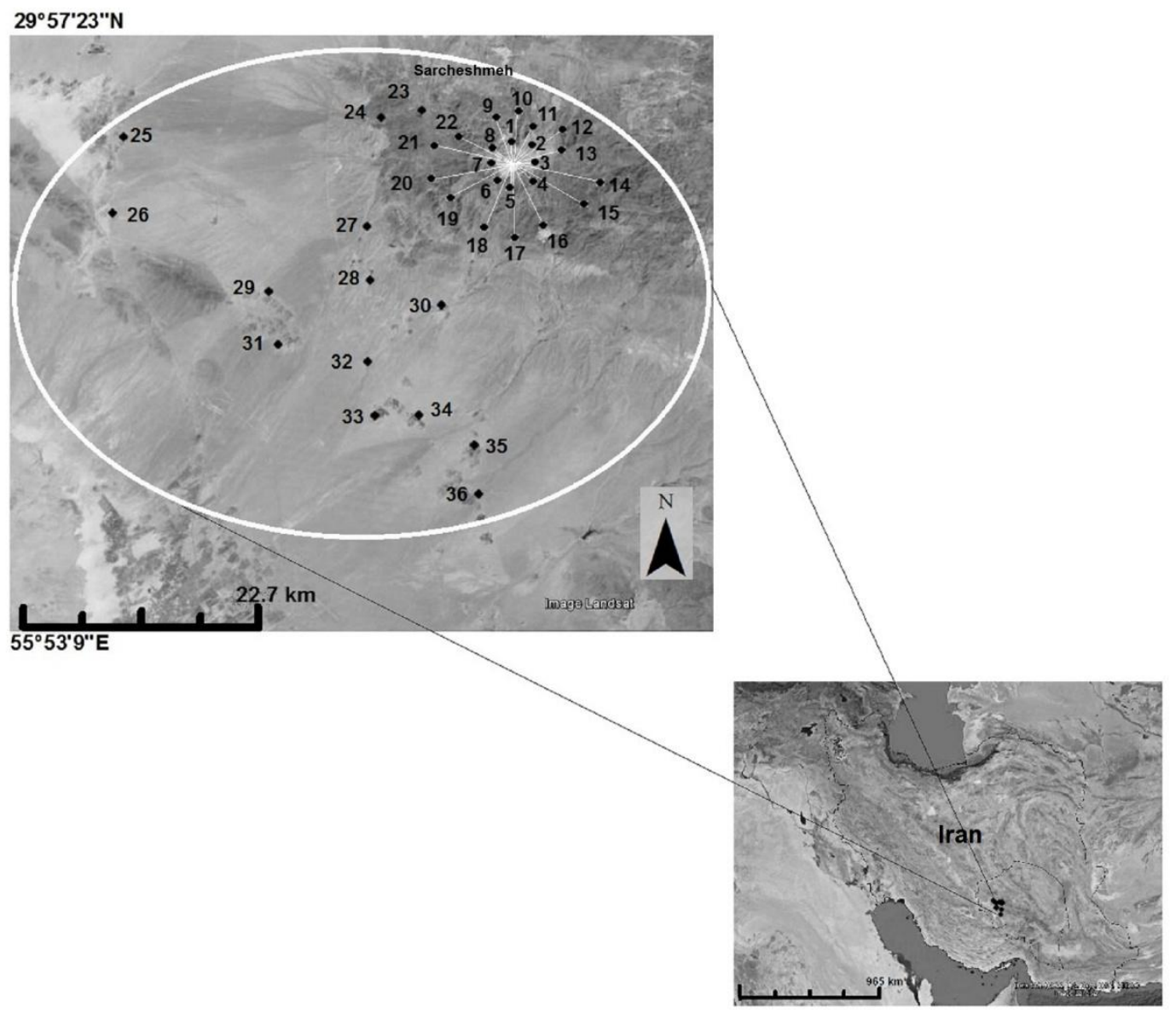

Figure 1. Location of samples selected in this study

Mining has occurred at the copper mine complex since 1972 and the extraction of copper has since increased from 15,000 tonnes to 70,000 tonnes (http://nicico.com). The surrounding agricultural region cultivated with pistachio contains saline, calcareous, and low organic material soils. Samples were taken from the soil surface using a random compound sampling strategy, which employed square method/stratification of sampling. Each studied sample comprised a mixture of five subsamples of each site from the vertices and centre of a 2.5 m square (Baker and Banfield, 2003; Garrity et al., 2005). Samples were preserved in sterile tubes $(50 \mathrm{ml})$ in an aseptic condition, immediately transported to the laboratory, and stored at $5^{\circ} \mathrm{C}$ and $-20^{\circ} \mathrm{C}$ in two series for dependent and independent culturing methods respectively. Complete data on soil samples are included in Table 1. Chemical characteristics of the soil samples, including $\mathrm{pH}$, electrical conductivity (EC, $\mathrm{dS} \mathrm{m} \mathrm{m}^{-1}$ ), and organic carbon (OC, \%) (Walkley and Black, 1934), were determined. The percentage of major chemical elements (aluminium ( $\mathrm{Al}$ ), arsenic $(\mathrm{As})$, calcium $(\mathrm{Ca})$, copper $(\mathrm{Cu})$, magnesium $(\mathrm{Mg})$, manganese $(\mathrm{Mn})$, lead $(\mathrm{Pb})$, zinc $(\mathrm{Zn})$, molybdenum (Mo), sulphur $(\mathrm{S})$, and iron $(\mathrm{Fe})$ ) were measured by atomic absorption spectrometry analysis (Schultz, 1964). 


$$
-512-
$$

Table 1. Chemical composition of copper mine soil samples (elements concentration in unit of \%, EC in unit of dS/m)

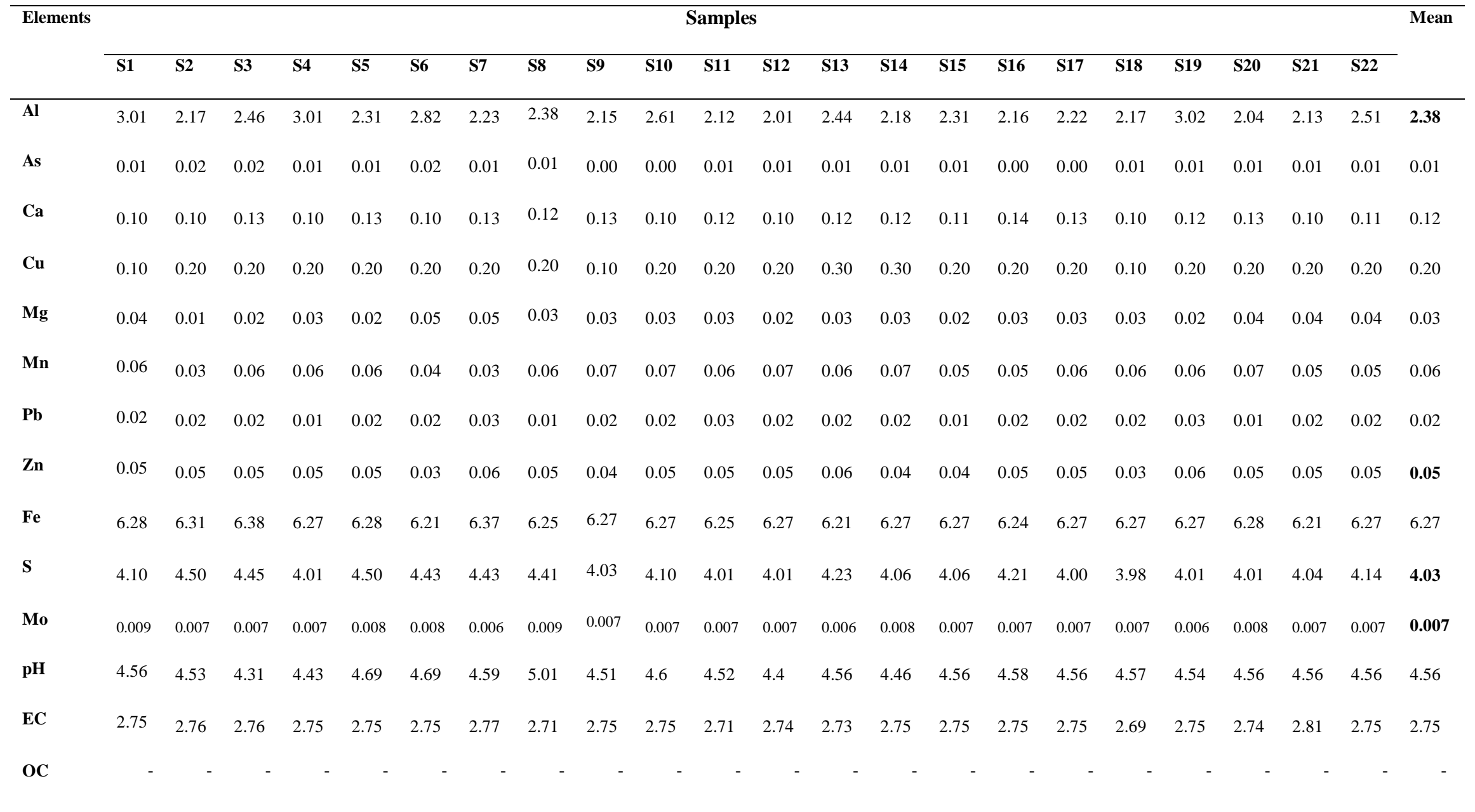


Continued Table 1. Chemical composition of agricultural soil samples

\begin{tabular}{|c|c|c|c|c|c|c|c|c|c|c|c|c|c|c|c|}
\hline \multirow[t]{2}{*}{ Elements } & \multicolumn{14}{|c|}{ Samples } & \multirow[t]{2}{*}{ Mear } \\
\hline & S23 & S24 & S25 & S26 & S27 & S28 & S29 & S30 & S31 & S32 & S33 & S34 & S35 & S36 & \\
\hline Al & 2.16 & 2.16 & 2.16 & 2.01 & 2.24 & 2.21 & 2.16 & 2.16 & 2.16 & 2.18 & 2.14 & 2.16 & 2.18 & 2.14 & 2.16 \\
\hline As & 0.03 & 0.02 & 0.02 & 0.02 & 0.02 & 0.03 & 0.02 & 0.02 & 0.02 & 0.02 & 0.02 & 0.02 & 0.02 & 0.02 & 0.02 \\
\hline $\mathrm{Ca}$ & 2.16 & 2.12 & 2.12 & 2.16 & 2.11 & 2.00 & 2.00 & 2.12 & 2.14 & 2.13 & 2.14 & 2.11 & 2.11 & 2.11 & 2.11 \\
\hline $\mathrm{Cu}$ & 0.30 & 0.32 & 0.32 & 0.31 & 0.31 & 0.31 & 0.32 & 0.30 & 0.31 & 0.31 & 0.31 & 0.31 & 0.30 & 0.30 & 0.31 \\
\hline Mg & 0.05 & 0.07 & 0.04 & 0.05 & 0.05 & 0.05 & 0.05 & 0.04 & 0.06 & 0.05 & 0.05 & 0.04 & 0.06 & 0.04 & 0.05 \\
\hline Mn & 0.14 & 0.10 & 0.13 & 0.12 & 0.12 & 0.10 & 0.13 & 0.12 & 0.11 & 0.10 & 0.13 & 0.12 & 0.10 & 0.11 & 0.12 \\
\hline $\mathbf{P b}$ & 0.02 & 0.02 & 0.01 & 0.03 & 0.04 & 0.01 & 0.01 & 0.02 & 0.02 & 0.03 & 0.02 & 0.02 & 0.02 & 0.02 & 0.02 \\
\hline $\mathbf{Z n}$ & 0.04 & 0.03 & 0.04 & 0.04 & 0.04 & 0.03 & 0.02 & 0.05 & 0.04 & 0.05 & 0.04 & 0.03 & 0.04 & 0.04 & 0.04 \\
\hline $\mathrm{Fe}$ & 6.91 & 6.87 & 6.91 & 6.94 & 6.88 & 6.91 & 6.91 & 6.91 & 6.91 & 6.96 & 6.98 & 6.91 & 6.92 & 6.82 & 6.91 \\
\hline Mo & 0.006 & 0.004 & 0.008 & 0.006 & 0.006 & 0.007 & 0.005 & 0.006 & 0.006 & 0.007 & 0.006 & 0.008 & 0.007 & 0.008 & 0.006 \\
\hline pH & 7.89 & 7.84 & 7.84 & 7.89 & 7.89 & 7.86 & 7.89 & 7.89 & 7.89 & 7.97 & 7.99 & 7.92 & 7.87 & 7.89 & 7.89 \\
\hline EC & 3.18 & 3.19 & 3.19 & 3.21 & 3.18 & 3.19 & 3.19 & 3.18 & 3.19 & 3.10 & 3.19 & 3.22 & 3.10 & 3.20 & 3.18 \\
\hline OC & 0.70 & 0.70 & 0.60 & 0.50 & 0.50 & 0.60 & 0.70 & 0.80 & 0.70 & 0.70 & 0.70 & 0.60 & 0.60 & 0.70 & 0.70 \\
\hline
\end{tabular}




\section{Cultivation-dependent SOB identification}

\section{Selective bacterial cultivation}

SOB isolation procedures were carried out according to Marsh and Norris (1983) with some modifications (Marsh and Norris, 1983). For SOB population screening in a culture medium, $0.2 \mathrm{mg}$ of each soil sample was used for culturing in 9K medium (Sigma-Aldrich, USA)( for the achievement of a more comprehensive diversity of sulfur oxidizing bacteria) with a pH of 3.5 or 6.5 to allow the acidophilic and neutrophilic SOB to growth (Schoenborn et al., 2004; Widawati et al., 2005). The samples were incubated at $120 \mathrm{rpm}, 30^{\circ} \mathrm{C}$ or $45^{\circ} \mathrm{C}$ for 14 days, and finally cultured on agar plates to separate the single colonies for morphophysiological confirmation. To isolate new bacteria, the culture medium was monitored for six months with two-week intervals. Morphological characteristics of colonies such as size, colour, surface, and colony boundary (Holt et al., 1994) were determined. Also, physiological characteristics such as sulphate concentration, $\mathrm{pH} / \mathrm{Eh}$, cellular growth, source of energy, aerobic/anaerobic, and temperature were measured (Bielefeldt et al., 2009). Confirmed SOB colonies were transferred to $-20^{\circ} \mathrm{C}$ for DNA extraction and subsequent applications.

\section{DNA extraction and 16S rRNA amplification}

The soil bacterial DNA was extracted using a QIAamp® Mini Kit (Qiagen, Germany) according to manual instructions. Extracted DNA quality was measured by $1 \%$ agarose gel electrophoresis and NanoDrop 2000c 260/280 nm spectrophotometry (Thermo Scientific, USA). Polymerase chain reaction (PCR) amplification of the full-length 16S rRNA gene was performed using 27f (5'-AGAGTTTGATCCTGGCTCAG-3') and 1492r (5'CGGTTACCTTGTTACGACTT-3') primers. For identification of uncultured bacteria according to DGGE, the primers used were 357f (5'-CGCCCGCCGCGCGCGGCGGGC GGGGCGGGGGCACGGGGGGACTCCTACGGGAGGCAGCAG-3') and 517r (5'-ATT ACC GCG GCT GCT GG-3'). PCR reactions were carried out in a gradient PEQLAB thermocycler (PEQLAB Biotechnologie, Germany) in a final volume of $50 \mu$ l containing 20 $\mu \mathrm{M}$ of each primer, 0.2 units/ $\mu \mathrm{l} \mathrm{Taq} \mathrm{DNA} \mathrm{polymerase} \mathrm{(Ampliqon,} \mathrm{Denmark),} \mathrm{PCR} \mathrm{buffer} 1 \mathrm{x}$ (Tris- $\mathrm{HCl} \mathrm{pH} \mathrm{8.5,}\left(\mathrm{NH}_{4}\right)_{2} \mathrm{SO}_{4}, 0.2 \%$ Tween20), $0.5 \mathrm{mM}$ dNTPs, $1.5 \mathrm{mM} \mathrm{MgCl}_{2}$, and 20-50 ng gDNA. The PCR amplification program was as follows: initial denaturation in $95^{\circ} \mathrm{C}$ for 5 min, 35 cycles of denaturation in $94^{\circ} \mathrm{C}$ for $30 \mathrm{~s}$, primer annealing in $59^{\circ} \mathrm{C}$ for $50 \mathrm{~s}$, extension in $72^{\circ} \mathrm{C}$ for $2 \mathrm{~min}$, and final extension in $72^{\circ} \mathrm{C}$ for $10 \mathrm{~min}$. PCR products of the full-length $16 \mathrm{~S}$ rRNA gene were cloned in a TA cloning vector using InsTAclone PCR Cloning Kit (Fermentas, USA) and sequenced bi-directionally using an ABI 3730 capillary sequencer. DGGE analysis of uncultured bacterial populations was performed in a D-code DGGE system (Muyzer and Smalla, 1998) with 8\% polyacrylamide gel and 40\%-75\% gradient of formamide at a $55^{\circ} \mathrm{C}$ buffer temperature. Electrophoresis ran at a constant electrical power of $70 \mathrm{v}$ for $17 \mathrm{~h}$ and gels were then stained in florescent safe stain $(0.5 \mu \mathrm{g} / \mathrm{ml})$, which were finally visualized in a G-box system (Syngene, UK). Each identified DGGE band was reamplified according to the above conditions and sequenced in triplicate.

\section{Data analysis}

Obtained sequences of the 16S rRNA gene from culture-dependent and -independent methods were checked in Chromas 2.01 (Technelysium Pty Ltd) and reviewed manually for any sequencing errors. Similar analysis of samples was performed in BLASTn software implemented on the National Center for Biotechnology Information homepage (http://www.ncbi.nlm.nih.gov/) and Ribosomal Database Project II and aligned using the 
clustalW program (Cole et al., 2005). Sequences with a similarity percentage greater than 97\% were selected as a species and an OTU (Stackebrandt et al., 2002). All identified sequences have been deposited in the GenBank data server with the following accession numbers: KR020042-KR020052 and KR065700-KR065720.

The diversity indices of copper mine and agricultural soil samples (S1-S36) and every OTU including the number of taxa $(\mathrm{S})$, Shannon index $(\mathrm{H})$, and Berger-Parker index were calculated in the statistical program PAST (http://folk.uio.no/ohammer/past/). In addition, frequency of each OTU in all samples and the comparison between the two sample environments (mine and agriculture) was investigated using analysis of similarities (ANOSIM). The pattern of bacterial distribution and inter-relationships with environmental characteristics (physicochemical properties) were measured using non-metric multidimensional scaling (N-MDS), according to the Bray-Curtis distance matrix (Clarke, 1993). A similarity percentage (SIMPER) calculation was used to find the most frequent OTU in each mine and agricultural sample. Cluster analysis of samples was processed with the un-weighted pair group method with arithmetic mean (UPGMA) based on Bray-Curtis dissimilarities and 1000 bootstrap replications.

\section{Results}

\section{Soil chemical analysis}

The results of chemical analyses of soil samples from the copper mine and its surroundings are shown in Table 1. Chemical comparison of samples indicated a significant difference between the two sites according to $\mathrm{pH}$ level, organic carbon, and calcium concentrations $\mathrm{p}<$ 0.05). Agricultural soil samples were neutral to slightly alkaline with a $\mathrm{pH}$ of 7.9, but copper mine soil samples were acidic with a $\mathrm{pH}$ of 4.56. Organic carbon content in the agricultural soil was $0.7 \%$, but it was not detected in the mine soil samples. EC values of copper mine and agricultural soil samples differed significantly $(\mathrm{P}<0.05)$ but the value was similar among all mine samples (almost $2 \mathrm{dS} / \mathrm{m})(\mathrm{P}>0.05)$. Except for $\mathrm{Pb}$, concentrations of other elements (Ca, As, $\mathrm{Al}, \mathrm{Zn}, \mathrm{S}, \mathrm{Cu}, \mathrm{Mg}, \mathrm{Mn}, \mathrm{Mo}$, and $\mathrm{Fe}$ ) differed in agricultural and mine soil samples. Thus, agricultural soil in contrast to copper mine soil had higher levels of organic matter and salinity and was measured as neutrophilic.

\section{Bacterial OTU identification}

According to Table 2 (2.1 and 2.2), different strains of SOB were isolated from mine soil sample using culture-dependent approach (after enrichment). Acidithiobacillus thiooxidans was isolated from samples S1 and S8 while from samples S4, S5, S8, S9, S12, S15, S16, S17, S19, S20 ,S22 and S2, S7, S14 Acidithiobacillus ferridurans and Sulfobacillus acidophilus were respectively isolated. In agricultural soil, different species of genus Thiobacillus include thiophilus, thioparus, aquaesulis respectively from samples S23, S32 and S24, S36 and S25, S26 and S27, S30, S28 and the Starkeya novella from S32 sample were isolated.

Results indicated that 19 main bacterial OTUs were identified. The culture-dependent $16 \mathrm{~S}$ rRNA almost full-length sequencing identified seven OTUs including four specific OTUs in agricultural soils and three specific OTUs in copper mine soils (Table 3). Bacterial isolates of agricultural soils belonged to Alphaproteobacteria (Starkya novella) and Betaproteobacteria (Thiobacillus thiophilus, Thiobacillus thioparus, Thiobacillus aquasulis), and in copper mine soils belonged to Gammaproteobacteria (Acidithiobacillus thiooxidans, Acidithiobacillus ferridurans) and Firmicutes (Sulfobacillus acidophilus). 
Table 2.1. Identification of SOB in samples at culture-dependent approach

\begin{tabular}{|c|c|c|c|c|c|c|c|c|c|c|c|c|c|c|c|c|c|c|c|c|c|c|c|c|}
\hline \multirow[t]{2}{*}{ Closest relative } & \multicolumn{22}{|c|}{ Mine soil sample } & \multirow{2}{*}{$\sum_{\text {Isolate }}$} & \multirow{2}{*}{$\begin{array}{c}\text { Relative } \\
\text { abundance } \\
(\%)\end{array}$} \\
\hline & S1 & S2 & S3 & S4 & S5 & S6 & S7 & S8 & S9 & S10 & S11 & S12 & S13 & S14 & S15 & S16 & S17 & S18 & S19 & $\mathrm{S} 20$ & S21 & S22 & & \\
\hline $\begin{array}{l}\text { Acidithiobacillus } \\
\text { thiooxidans }\end{array}$ & $*$ & & & & & & & $*$ & & & & & & & & & & & & & & & 2 & 7.69 \\
\hline $\begin{array}{l}\text { Acidithiobacillus } \\
\text { ferridurans }\end{array}$ & & & & $*$ & $*$ & & & $*$ & $*$ & & & $*$ & & & $*$ & $*$ & $*$ & & $*$ & $*$ & & $*$ & 11 & 42.31 \\
\hline $\begin{array}{l}\text { Sulfobacillus } \\
\text { acidophilus }\end{array}$ & & $*$ & & & & & $*$ & & & & & & & $*$ & & & & & & & & & 3 & 11.54 \\
\hline$\sum$ Isolate & 1 & 1 & & 1 & 1 & & 1 & 2 & 1 & & & 1 & & 1 & 1 & 1 & 1 & & 1 & 1 & & 1 & 16 & 61.54 \\
\hline $\begin{array}{l}\text { Relative } \\
\text { abundance (\%) }\end{array}$ & 3.85 & 3.85 & & 3.85 & 3.85 & & 3.85 & 7.69 & 3.85 & & & 3.85 & & 3.85 & 3.85 & 3.85 & 3.85 & & 3.85 & 3.85 & & 3.85 & & \\
\hline
\end{tabular}

Table 2.2. Identification of SOB in samples at culture-dependent approach

\begin{tabular}{|c|c|c|c|c|c|c|c|c|c|c|c|c|c|c|c|c|}
\hline \multirow[t]{2}{*}{ Closest relative } & \multicolumn{14}{|c|}{ Agricultural soil sample } & \multirow{2}{*}{$\begin{array}{l}\sum \\
\text { Isolate }\end{array}$} & \multirow{2}{*}{$\begin{array}{l}\text { Relative } \\
\text { abundance }(\%)\end{array}$} \\
\hline & S23 & S24 & $\mathrm{S} 25$ & S26 & S27 & S28 & S29 & $\mathrm{S} 30$ & S31 & S32 & S33 & S34 & S35 & S36 & & \\
\hline Thiobacillus thiophilus & $*$ & & & & & & & & & $*$ & & & & & 2 & 7.69 \\
\hline Thiobacillus thioparus & & $*$ & & & & & & & & & & & & $*$ & 2 & 7.69 \\
\hline Thiobacillus aquaesulis & & & $*$ & $*$ & & & & & & & & & & & 2 & 7.69 \\
\hline Starkeya novella & & & & & $*$ & $*$ & & $*$ & & $*$ & & & & & 4 & 15.38 \\
\hline$\sum$ Isolate & 1 & 1 & 1 & 1 & 1 & 1 & & 1 & & 2 & & & & 1 & 10 & 38.46 \\
\hline Relative abundance (\%) & 3.85 & 3.85 & 3.85 & 3.85 & 3.85 & 3.85 & & 3.85 & & 7.69 & & & & 3.85 & & \\
\hline
\end{tabular}


Table 3. List of identified bacterial species and OTUs in agricultural and mine soil samples

\begin{tabular}{|c|c|c|c|c|c|c|c|}
\hline Method & Sample & $\begin{array}{l}\text { SOB/non- } \\
\text { SOB }\end{array}$ & Putative Division & Genus & $\begin{array}{l}\text { Closest relative } \\
\text { (Species,OUT) }\end{array}$ & $\begin{array}{c}\text { Accesion } \\
\text { No }\end{array}$ & $\begin{array}{c}\text { Similarity } \\
(\%)\end{array}$ \\
\hline $\begin{array}{l}\text { Non- } \\
\text { cultured }\end{array}$ & Mine & SOB & Gammaproteobacteria & Acidithiobacillus sp. & $\begin{array}{l}\text { Acidithiobacillus } \\
\text { ferrooxidans }\end{array}$ & KM 527215 & 99.9 \\
\hline \multirow[t]{15}{*}{ (DGGE) } & & & & & $\begin{array}{l}\text { Acidithiobacillus } \\
\text { ferridurans }\end{array}$ & NR 117036 & 99.9 \\
\hline & & & & & Acidithiobacillus caldus & NR 102970 & 99.9 \\
\hline & & non- SOB & Firmicutes & Bacillus sp. & Bacillus megaterium & KP 017584 & 99.9 \\
\hline & & & & & Bacillus subtilis & GQ 267463 & 99.5 \\
\hline & & non- SOB & Cyanobacteria & Halospirulina sp. & Halospirulina sp. & AB 900936 & 99.8 \\
\hline & & non- SOB & Alphaproteobacteria & Sphingobium sp. & Sphingobium yanoikuyae & KP 313542 & 99.9 \\
\hline & & non- SOB & Gammaproteobacteria & Pseudomonas sp. & Pseudomonas syringae & KP 09980 & 99.2 \\
\hline & & & & & Pseudomonas sp. & KJ 413318 & 99.9 \\
\hline & & non- SOB & Actinobacteria & $\begin{array}{l}\text { Propionibacterium } \\
\text { sp. }\end{array}$ & Propionibacterium sp. & GU 332269 & 99.8 \\
\hline & & non- SOB & Gammaproteobacteria & Acinetobacter sp. & Acinetobacter johnsonii & LN 774358 & 99.9 \\
\hline & & non- SOB & Alphaproteobacteria & Sphingomonas sp. & Sphingomonas sp. & DQ 923856 & 99.9 \\
\hline & Agri & non- SOB & Firmicutes & Bacillus sp. & Bacillus megaterium & KP 017584 & 99.9 \\
\hline & & & & & Bacillus subtilis & GQ 267463 & 99.5 \\
\hline & & non- SOB & Alphaproteobacteria & Sphingobium sp. & Sphingobium yanoikuyae & KP 313542 & 99.9 \\
\hline & & non- SOB & Gammaproteobacteria & Pseudomonas sp. & Pseudomonas syringae & KP 09980 & 99.2 \\
\hline
\end{tabular}




\begin{tabular}{|c|c|c|c|c|c|c|c|}
\hline & & & & & Pseudomonas sp. & KJ 413318 & \\
\hline & & non- SOB & Actinobacteria & Propionibacterium & Propionibacterium sp. & GU 332269 & 99.8 \\
\hline & & & & $s p$ & & & \\
\hline & & non- SOB & Actinobacteria & Streptomyces sp. & Streptomyces sp. & LN 649246 & 99.8 \\
\hline & & non- SOB & Gammaproteobacteria & Acinetobacter sp. & Acinetobacter johnsonii & LN 774358 & 99.9 \\
\hline \multirow[t]{9}{*}{ Cultured } & \multirow[t]{5}{*}{ Mine } & SOB & Gammaproteobacteria & Acidithiobacillus sp. & Acidithiobacillus & NR 115265 & 95.0 \\
\hline & & & & & thiooxidans & & \\
\hline & & & & & Acidithiobacillus & NR 117036 & 95.0 \\
\hline & & & & & ferridurans & & \\
\hline & & SOB & Firmicutes & Sulfobacillus sp. & Sulfobacillus acidophilus & NR 074758 & 94.6 \\
\hline & \multirow[t]{4}{*}{ Agri } & SOB & Betaproteobacteria & Thiobacillus sp. & Thiobacillus thiophilus & NR 044555 & 93.9 \\
\hline & & & & & Thiobacillus thioparus & NR 117864 & 93.9 \\
\hline & & & & & Thiobacillus aquaesulis & NR 117675 & 99.9 \\
\hline & & SOB & Alphaproteobacteria & Starkeya sp. & Starkeya novella & NR 074219 & 95.3 \\
\hline
\end{tabular}




\section{Culture-independent approach}

Table 4 (4.1, 4.2 and 4.3) shows the identification of bands in samples in the DGGE banding patterns (shown in Figure 2a, $b$ and c). Based on Table 4 (4.1, 4.2, 4.3) 156 bands were detected from all samples. The samples were heterogeneous in terms of the number of bands in DGGE pattern. Samples exhibiting just 1 band (S31, S26, S24, S23, S35 and S36) belonged to agricultural samples while samples containing the highest number of bands belonged to mine samples (The samples S1, S2, S3, and S5 7 bands; S16, 9 bands; S12, and S4, 10 bands). This ceases can be concerned to role of climate. Since the climate of the study area was dry, and in the terms of the year was associated with dryness, in such conditions, growth of bacteria can be difficult and it was resulted in a lower band number was found in agricultural soil. While in mining copper, because of copper bioleaching processes and copper mining, medium had the water and thus provides the conditions for the growth of bacteria and as a result, more bands were observed in mine samples.

Both mine and agricultural samples containing 2, 3, 4, 5, 6 bands belonged to sample groups (S25, S10, S33, S34), (S22), (S13, S14, S15, S32), (S28, S7, S18, S19), ( S20), (S6, S29, S30, S8) and (S27, S9, S11, S17, S21) respectively. Therefore, minimum number of bands appeared in agricultural soil samples and the maximum number of bands appeared in mine samples. On the other hand heterogeneity among mine samples was higher than for the agricultural soil samples.

As shown in Table 4.1, S1 sample exhibited 7 bands in where 2 belonged to Acidithiobacillus sp., (coincident among samples S2, S3, S4, S5 and S6), 2 bands belonged to Bacillus sp., (these bands were coincident among samples S2, S3, S4, S5, S6, S27, S28, S29 and S30) and 3 bands belonged to Pseudomonas sp. (coincident among samples S1, S2, S3, S4, S5, S6, S27, S28, S29, S30 and S31). Sample S4 contain 10 bands which is visible coincident among S1 sample, except one band that belongs to Halospirulina sp. Also, S5 sample has 7 bands which in 6 bands were resemble to S4 sample and one band that belong to Sphingobium $s p$ was different. Similar result observed only in samples S2, S3, S4 and S30.

As shown on Table 4.2, the samples S9 and S11 exhibited 6 bands, 3 bands belonging to Acidithiobacillus sp., (coincident among samples S7, S8 and S10), 1 band belonging to Propionibacterium sp., (coincident among samples S23, S7, S25, S8, S26, S10), 1 band belong to Acinetobacter sp (coincident among samples S7, S25, S8) and finally, 1 band belonged to Bacillus sp. S24 sample exhibited only 1 band that belonged to Streptomyces $s p$. Coincident among samples (S17, S18, S21 and S22), 1 band belong to Halospirulina sp. (this band was coincident among samples S12, S17, S22), 3 bands belonging to Pseudomonas sp. (coincident among samples S12, S13, S14, S15, S17, S18, S19, S32, S20, S33, S21, S34, S35), 1 band belonging to Sphingobium sp. (coincident among samples S18, S22 and S36) and 1 band belonging to Acinetobacter sp. (coincident among samples S12, S20, S21). The samples 17 and 18 included only one band that belonged to Sphingomonas sp.

The most important difference between mine and agricultural samples were related to the occurrence of the genera Acidithiobacillus sp, Streptomyces sp and Acidithiobacillus sp., which were exclusively found in the mine soil samples. While in agricultural samples only Streptomyces $s p$ was dominant.

The result of DGGE of the V3 region of the 16S rRNA gene indicated 12 bacterial OTUs in copper mine soils and 8 OTUs in agricultural soils (Table 3). Mine bacterial populations included Alphaproteobacteria, Gammaproteobacteria, Firmicutes, Cyanobacteria, and Actinobacteria, of which only the species Gammaproteobacteria belonged to SOB. In agricultural soil samples, all previously mentioned mine bacterial species, except cyanobacteria, were identified as non-SOB. 


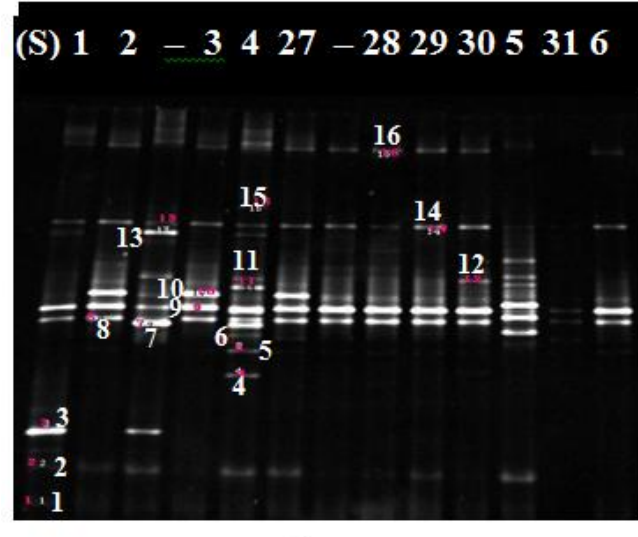

a $\begin{array}{lll}23 & 7 & 24\end{array}$

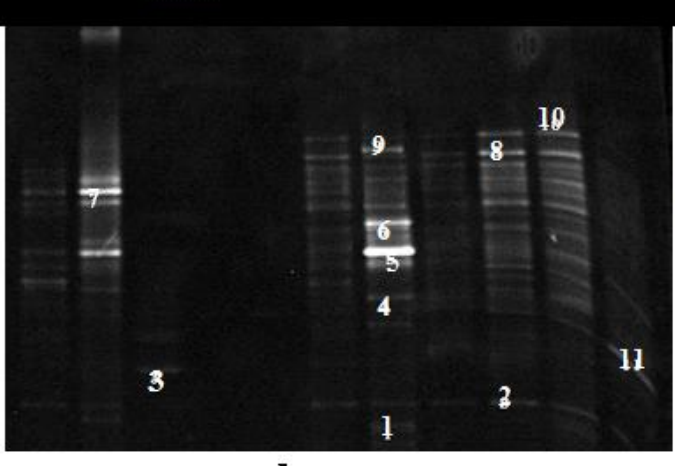

b
121314151617181932203321343622

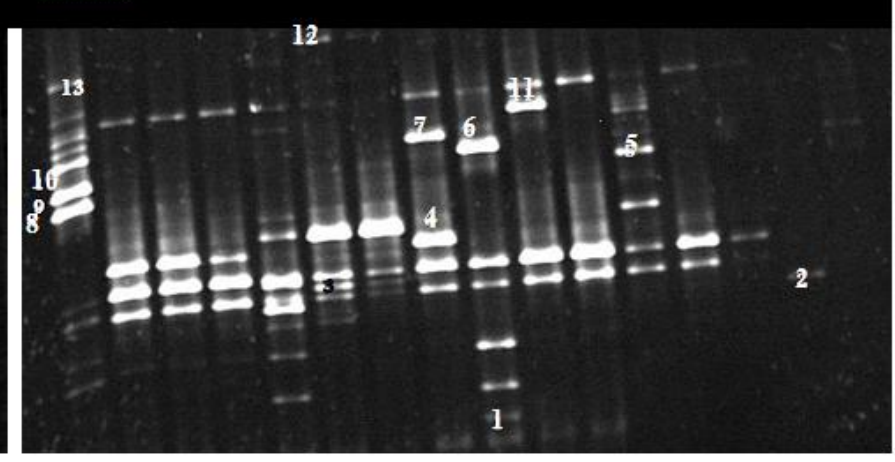

c

Figure 2. DGGE profiles of PCR amplicons of $16 \mathrm{~S}$ rDNA

The position of bands is indicated by numbers that correspond to species of bacterial.

a, 1: Acidithiobacillus ferrooxidans; 2: Bacillus sp.; 3: Acidithiobacillus ferridurans; 4: Sphingobium sp.; 5: not detected; 6: Halospirulina sp.; 7: Acidithiobacillus ferridurans; 8: not detected; 9: Pseudomonas sp.; 10: Pseudomonas sp.; 11: Sphingobium sp.; 12: Sphingobium sp.; 13: Acinetobacter sp.;14: Pseudomonas sp.; 15: Bacillus sp.; 16: Pseudomonas sp.

b, 1: Acidithiobacillus ferrooxidans; 2: Propionibacterium sp.; 3: Streptomyces sp.; 4: not detected; 5: Acidithiobacillus ferridurans; 6: Acidithiobacillus ferridurans; 7: Acinetobacter johnsonii; 8: not detected; 9: not detected; 10: Bacillus sp.; 11: Acidithiobacillus caldus.

c, 1: not detected; 2: Halospirulina sp.; 3: Sphingomonas sp.; 4: Bacillus sp.; 5: Bacillus sp.; 6: Pseudomonas sp; 7: Pseudomonas sp; 8: Pseudomonas sp; 9: Pseudomonas sp; 10: Pseudomonas sp; 11: Pseudomonas sp; 12: Sphingobium sp.; 13: Pseudomonas sp. 
Table 4.1. Identification of bands in samples at DGGE banding patterns based on Figure 2 (a)

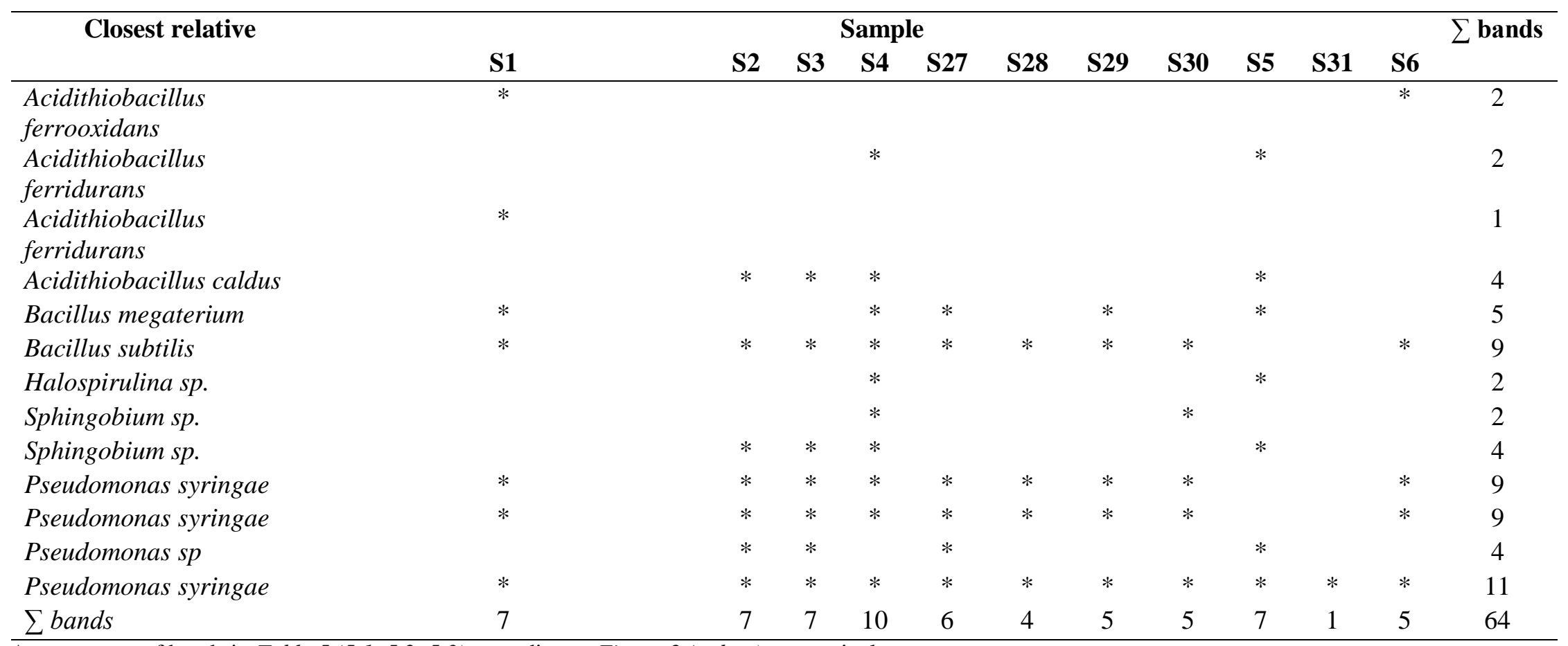

Arrangement of bands in Table $5(5.1,5.2,5.3)$ according to Figure $2(a, b, c)$, respectively. 
Table 4.2. Identification of bands in samples at DGGE banding patterns based on Figure $2(b)$

\begin{tabular}{|c|c|c|c|c|c|c|c|c|c|c|}
\hline \multirow[b]{2}{*}{ Closest relative } & \multicolumn{9}{|c|}{ Sample } & \multirow[t]{2}{*}{$\sum$ bands } \\
\hline & $\mathbf{S 2 3}$ & S7 & $\mathbf{S 2 4}$ & $\mathbf{S 2 5}$ & S8 & S26 & S9 & S11 & S10 & \\
\hline Acidithiobacillus ferrooxidans & & & & & $*$ & & & & & 1 \\
\hline \multirow[t]{2}{*}{ Acidithiobacillus ferridurans } & & $*$ & & & $*$ & & $*$ & $*$ & & 4 \\
\hline & & & & & $*$ & & $*$ & $*$ & & 3 \\
\hline Acidithiobacillus caldus & & $*$ & & & & & $*$ & $*$ & $*$ & 4 \\
\hline Propionibacterium sp. & $*$ & $*$ & & $*$ & $*$ & $*$ & $*$ & $*$ & $*$ & 8 \\
\hline Streptomyces sp. & & & $*$ & & & & & & & 1 \\
\hline Acinetobacter johnsonii & & $*$ & & $*$ & $*$ & & $*$ & $*$ & & 5 \\
\hline Bacillus subtilis & & & & & & & $*$ & $*$ & & 2 \\
\hline$\sum$ bands & 1 & 4 & 1 & 2 & 5 & 1 & 6 & 6 & 2 & 28 \\
\hline
\end{tabular}


Table 4.3. Identification of bands in samples at DGGE banding patterns based on Figure 2 (c)

\begin{tabular}{|c|c|c|c|c|c|c|c|c|c|c|c|c|c|c|c|c|c|}
\hline \multirow[b]{2}{*}{ Closest relative } & \multicolumn{16}{|c|}{ Sample } & \multirow{2}{*}{$\sum_{\text {bands }}$} \\
\hline & $\mathbf{S 1 2}$ & S13 & S14 & S15 & S16 & S17 & S18 & S19 & $\mathbf{S 3 2}$ & $\mathbf{S 2 0}$ & S33 & S21 & S34 & S35 & S36 & $\mathbf{S 2 2}$ & \\
\hline $\begin{array}{l}\text { Acidithiobacillus } \\
\text { ferrooxidans }\end{array}$ & & & & & $*$ & & & & & & & & & & & $*$ & 2 \\
\hline $\begin{array}{l}\text { Acidithiobacillus } \\
\text { ferrooxidans }\end{array}$ & & & & & $*$ & $*$ & & & & & & & & & & & 2 \\
\hline $\begin{array}{l}\text { Acidithiobacillus } \\
\text { ferrooxidans }\end{array}$ & & & & & $*$ & $*$ & $*$ & & & & & $*$ & & & & & 4 \\
\hline Halospirulina sp. & $*$ & & & & $*$ & $*$ & & & & & & & & & & $*$ & 4 \\
\hline Sphingomonas sp. & & & & & & $*$ & $*$ & & & & & & & & & & 2 \\
\hline Bacillus subtilis & & $*$ & $*$ & $*$ & & & & $*$ & & & & & & & & & 4 \\
\hline Bacillus subtilis & & & & & & & & & & & & $*$ & & & & & 1 \\
\hline Pseudomonas sp & & & & & & & & & $*$ & & & & & & & & 1 \\
\hline Pseudomonas sp & $*$ & & & & & & & $*$ & & & & $*$ & & & & & 3 \\
\hline Pseudomonas sp & $*$ & & & & & & & & & & & & & & & & 1 \\
\hline $\begin{array}{l}\text { Pseudomonas } \\
\text { syringae }\end{array}$ & $*$ & & & & & & & & & & & & & & & & 1 \\
\hline Pseudomonas sp & $*$ & & & & & & & & & & & & & & & & 1 \\
\hline Pseudomonas sp & $*$ & & & & $*$ & & & & & $*$ & & $*$ & & & & & 4 \\
\hline Pseudomonas sp & $*$ & & & & & & & & & & & & & & & & 1 \\
\hline $\begin{array}{l}\text { Pseudomonas } \\
\text { syringae }\end{array}$ & $*$ & $*$ & $*$ & $*$ & $*$ & $*$ & & $*$ & $*$ & $*$ & $*$ & & $*$ & & & & 11 \\
\hline $\begin{array}{l}\text { Pseudomonas } \\
\text { syringae }\end{array}$ & $*$ & $*$ & $*$ & $*$ & $*$ & $*$ & $*$ & $*$ & $*$ & $*$ & $*$ & $*$ & $*$ & $*$ & & & 14 \\
\hline $\begin{array}{l}\text { Sphingobium } \\
\text { yanoikuyae }\end{array}$ & & & & & & & $*$ & & & & & & & & $*$ & $*$ & 3 \\
\hline $\begin{array}{l}\text { Sphingobium } \\
\text { yanoikuyae }\end{array}$ & & & & & $*$ & & & & & & & & & & & & 1 \\
\hline $\begin{array}{l}\text { Acinetobacter } \\
\text { johnsonii }\end{array}$ & $*$ & & & & $*$ & & & & & $*$ & & $*$ & & & & & 4 \\
\hline$\sum$ bands & 10 & 3 & 3 & 3 & 9 & 6 & 4 & 4 & 3 & 4 & 2 & 6 & 2 & 1 & 1 & 3 & 64 \\
\hline
\end{tabular}

APPLIED ECOLOGY AND ENVIRONMENTAL RESEARCH 14(3): 509-533.

http://www.aloki.hu • ISSN 15891623 (Print) • ISSN 17850037 (Online)

DOI: http://dx.doi.org/10.15666/aeer/1403_509533

๑ 2016, ALÖKI Kft., Budapest, Hungary 
Table 5. Mean abundance of bacterial populations of copper mine and surrounding agricultural soil samples

\begin{tabular}{|c|c|c|c|c|c|c|c|}
\hline \multirow[t]{2}{*}{ Sub Class } & \multicolumn{2}{|c|}{$\begin{array}{c}\text { Relative } \\
\text { Abundance, \% }\end{array}$} & \multirow[t]{2}{*}{ Taxon } & \multirow[t]{2}{*}{$\begin{array}{c}\text { Av. } \\
\text { Dissim }\end{array}$} & \multirow[t]{2}{*}{$\begin{array}{c}\text { Contrib, } \\
\%\end{array}$} & \multicolumn{2}{|c|}{$\begin{array}{c}\text { Relative } \\
\text { Abundance,\% }\end{array}$} \\
\hline & Mine & Ag & & & & Mine & Ag \\
\hline \multirow[t]{7}{*}{ Gammaproteobacteria } & 63.3 & 38.8 & Acidithiobacillus ferridurans & 7.99 & 10.65 & 12.87 & 0.00 \\
\hline & & & Acidithiobacillus thiooxidans & 0.63 & 0.84 & 0.99 & 0.00 \\
\hline & & & Pseudomonas sp. & 7.42 & 9.89 & 11.87 & 10.81 \\
\hline & & & Pseudomonas syringae & 6.34 & 8.44 & 14.84 & 23.94 \\
\hline & & & Acinetobacter johnsonii & 5.39 & 7.18 & 7.92 & 3.63 \\
\hline & & & Acidithiobacillus ferrooxidans & 4.47 & 5.96 & 6.92 & 0.00 \\
\hline & & & Acidithiobacillus caldus & 5.00 & 6.66 & 7.92 & 0.00 \\
\hline \multirow[t]{3}{*}{ Alphaproteobacteria } & 8.9 & 19.1 & Sphingobium yanoikuyae & 4.92 & 6.56 & 6.92 & 5.76 \\
\hline & & & Sphingomonas sp. & 1.19 & 1.58 & 1.98 & 0.00 \\
\hline & & & Starkeya novella & 4.18 & 5.57 & 0.00 & 13.43 \\
\hline Cyanobacteria & 5.9 & 0 & Halospirulina sp. & 3.66 & 4.87 & 5.95 & 0.00 \\
\hline \multirow[t]{3}{*}{ Betaproteobacteria } & 0 & $16^{-}$ & Thiobacillus thiophilus & 1.77 & 2.36 & 0.00 & 5.26 \\
\hline & & & Thiobacillus thioparus & 2.19 & 2.91 & 0.00 & 5.56 \\
\hline & & & Thiobacillus aquaesulis & 2.04 & 2.71 & 0.00 & 5.26 \\
\hline \multirow[t]{3}{*}{ Firmicutes } & 16.8 & 15.7 & Sulfobacillus acidophilus & 1.96 & 2.61 & 2.97 & 0.00 \\
\hline & & & Bacillus subtilis & 7.48 & 9.97 & 11.87 & 10.51 \\
\hline & & & Bacillus megaterium & 2.34 & 3.12 & 1.98 & 5.26 \\
\hline \multirow[t]{2}{*}{ Actinobacteria } & 4.9 & 10.5 & Streptomyces sp. & 1.09 & 1.46 & 0.00 & 2.63 \\
\hline & & & Propionibacterium sp. & 5.00 & 6.66 & 4.95 & 7.87 \\
\hline
\end{tabular}


The frequency and relative frequency (abundance) of identified bacterial OTUs in mine and agriculture environments as well as each sample are indicated in Figures 3 and 4, respectively. Although Pseudomonas syringae in both environments had the highest frequency and relative frequency (14.84\% and $23.64 \%$, respectively), significant differences in Alpha- and Betaproteobacteria distribution were observed (Table 5). The dominant taxa of copper mine soil samples were Pseudomonas, Acidithiobacillus (At. thiooxidans, At. ferridiurans and At. caldus), and Bacillus bacteria, while in the agricultural environment it was Thiobacillus bacteria (Th. thiophilus, Th. thioparus, Th. aquasulis). SOB including Acidithiobacillus ferrooxidans, Acidithiobacillus ferridurans, Acidithiobacillus thiooxidans, and Acidithiobacillus caldus had relative frequency of $6 \%, 13 \%, 1 \%$, and, $7 \%$ respectively. The major OTUs that helped differentiate between the two environments were At. ferridurans, Bacillus subtilis, Pseudomonas sp., and Pseudomonas syringae (contribution of 10.65, 9.97, 9.89, and 8.44 , respectively).

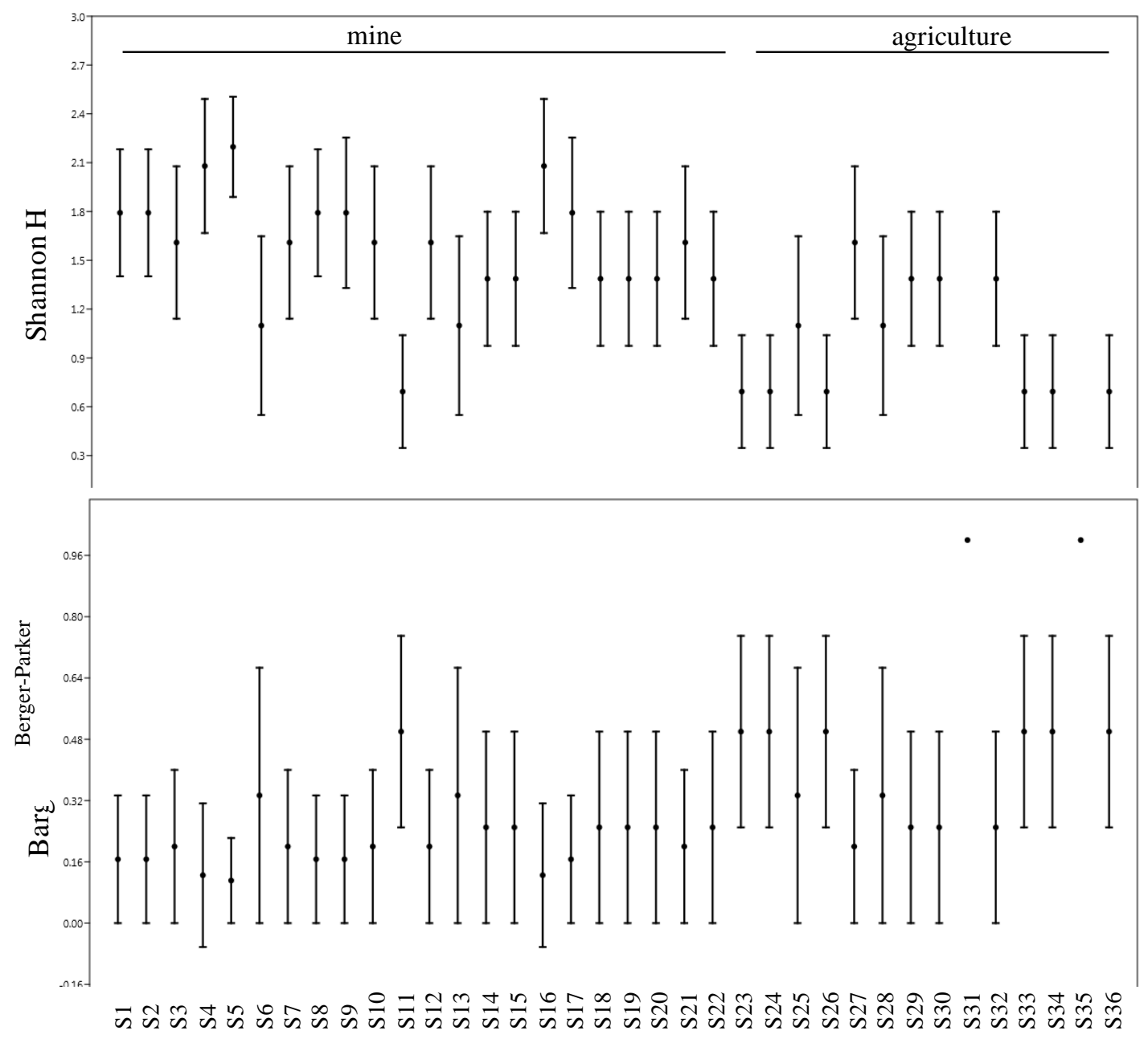

Figure 3. Estimates of bacterial diversity indices in agricultural and mine samples 


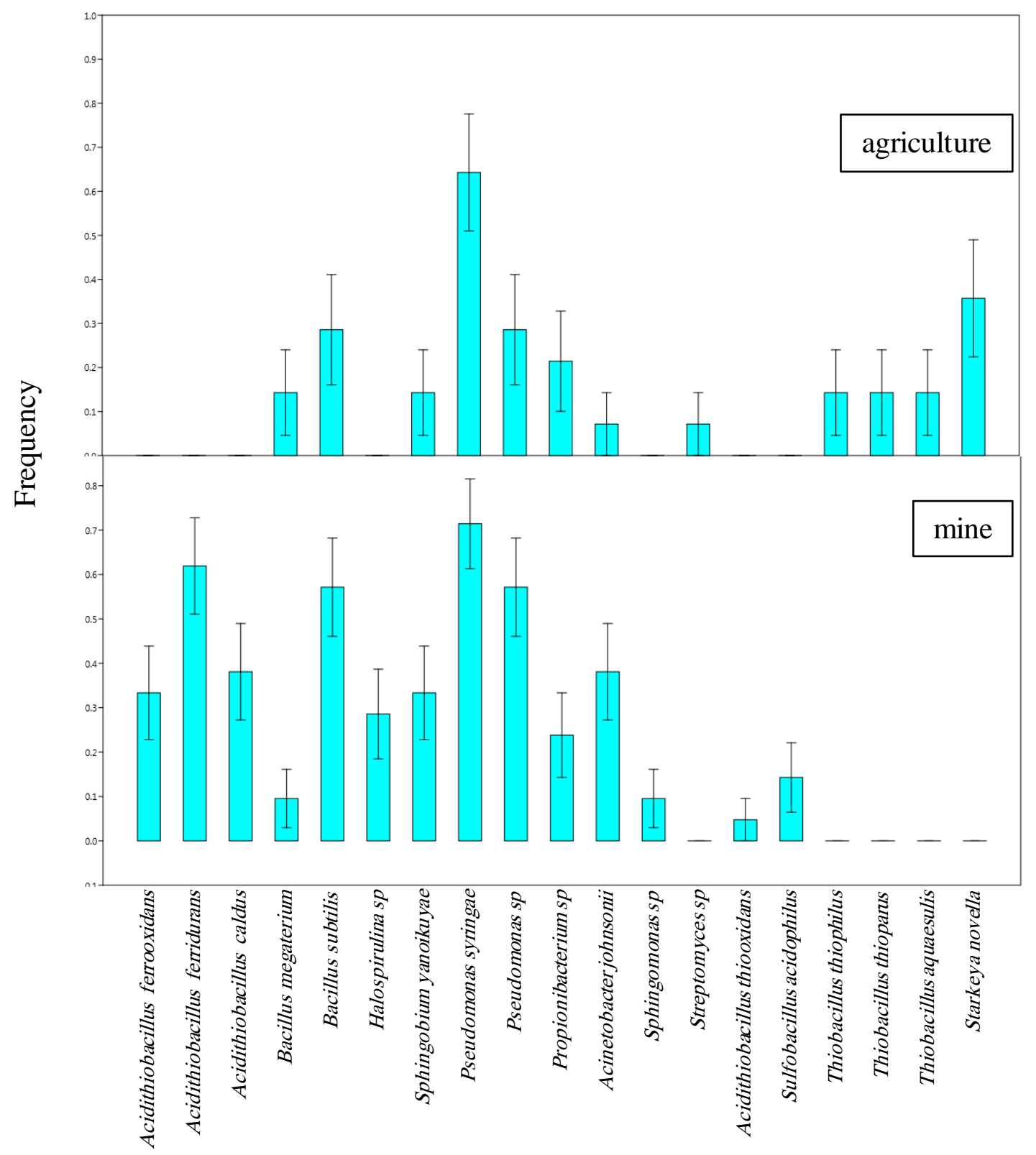

Figure 4. Frequency of identified bacterial populations in mine and agricultural environments

Results of diversity indices of different mine and agricultural soils are indicated in Figure 5. A comparison of resultant Shannon $\mathrm{H}$ values revealed that the bacterial diversity of the copper mine area was greater than the agricultural soils (mean $\mathrm{H}$ value: 1.57 and 0.87 , respectively). According to these results, the samples from the southward area of the copper mine (S4, S5, and S16 samples) had the greatest bacterial diversity and samples from the northward area (S11 and S13 samples) had the lowest bacterial diversity. In addition, agricultural soil samples near the southward area of the mine (S27, S28, and S30) had more bacterial diversity in comparison with the other samples. In contrast, the Berger-Parker index indicated that agricultural soil samples had more dominant OTUs than mine soil samples $(\mathrm{d}=0.47$ vs. 0.22$)$. In addition, the reciprocal 
value of the Berger-Parker index confirmed more diversity of bacterial populations in mine soil samples $(1 / \mathrm{d}=4.52$ vs. 2.11$)$.

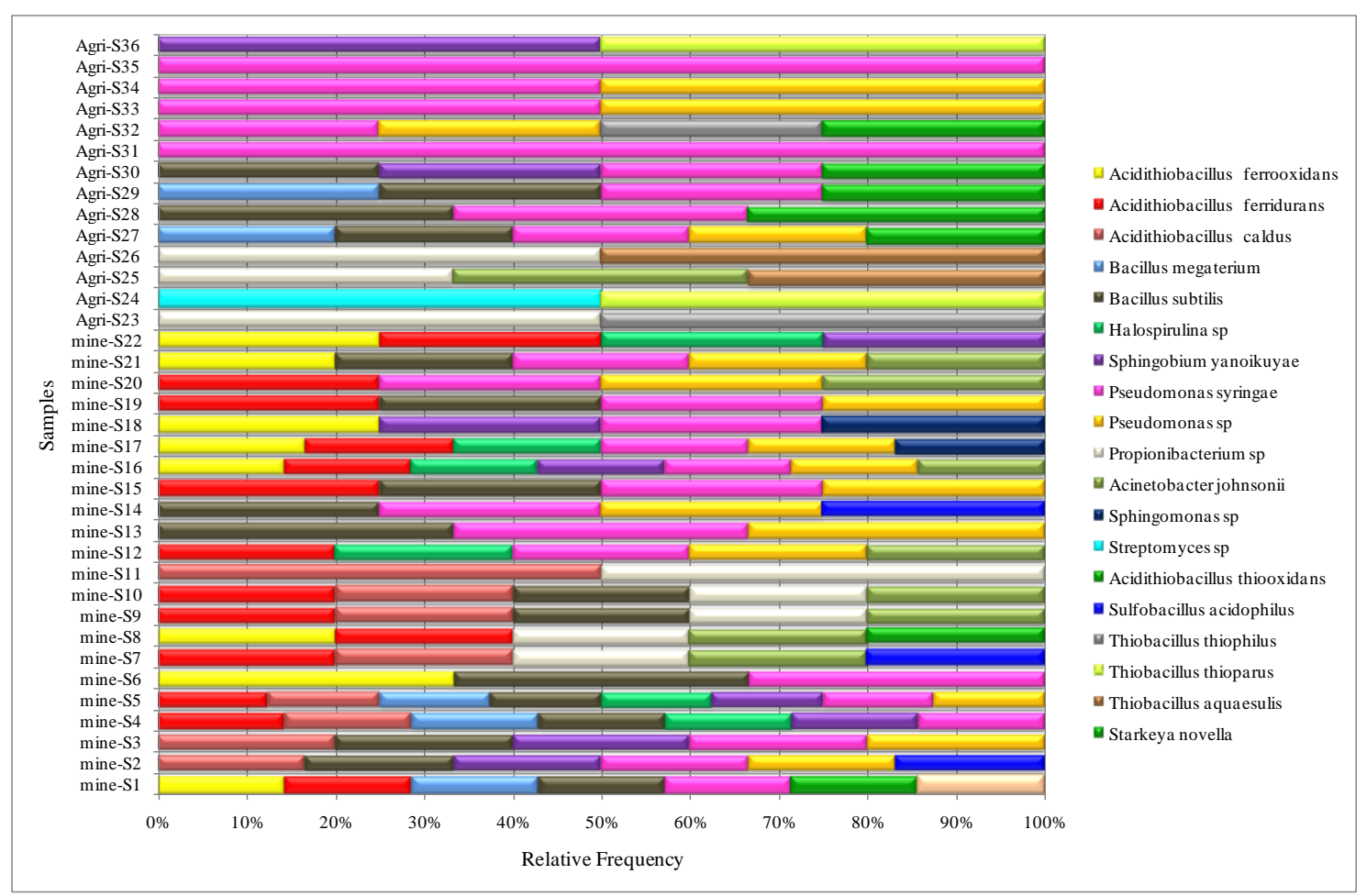

Figure 5. Relative frequency of identified bacteria of mine and agricultural soil samples (S1-S36)

Analysis of the similarities between mine and agricultural samples and identified OTUs revealed a significant difference related to environmental conditions $(R=0.2565$, $\mathrm{P}=0.001$ ). UPGMA cluster analysis indicated the coordinate result with the ANOSIM method with two separated clusters that belonged to each environmental type (Figure 6 ). The result of non-metric multidimensional scaling (N-MDS) suggested a large dissimilarity between bacterial population structures in the mine and surrounding agricultural soils with a stress value of 0.1864 , as shown in Figure 7 . The pattern of environmental distribution in the N-MDS plot indicated the importance of sulphur and, to a smaller extent, $\mathrm{Al}, \mathrm{Zn}$, and Mo in determining bacterial communities in the copper mine environment. The bacterial communities of the agricultural soil samples had an association with a mixture of environmental parameters such as $\mathrm{Ca}, \mathrm{OC}, \mathrm{pH}$, and other elements (Fe, As, $\mathrm{Mg}, \mathrm{Mn}$, and cobalt (Co)). Contributions of these elements and environmental factors in determining bacterial communities in the two types of soils was revealed by principal components analysis (PCA), as shown in Figure 8. Sulphur and calcium were the main environmental elements that could influence the $\mathrm{pH}$ of the soil and prepare conditions for acidophilic, neutrophilic, and alkalophilic bacterial populations. Therefore, the copper mine soil samples had a high concentration of sulphur $(4.16 \pm 0.04 \%)$ and a low $\mathrm{pH}$ value $(\mathrm{pH}=4.5)$ which caused the colonization of acidophilic bacterial species such as Acidithiobacillus sp. and Sulfobacillus sp. with greater abundance than other neutrophilic bacteria. On the other hand, agricultural soil samples had a low concentration of sulphur $(0.56 \pm 0.004 \%)$, a high concentration of calcium $(2.10 \pm 0.013 \%)$, and a higher $\mathrm{pH}$ value $(\mathrm{pH}=7.8)$, which eliminated the 
growth of the aforementioned acidophilic bacteria and induced the proliferation of neutrophilic bacterial populations such as Thiobacillus sp. and Starkeya sp.

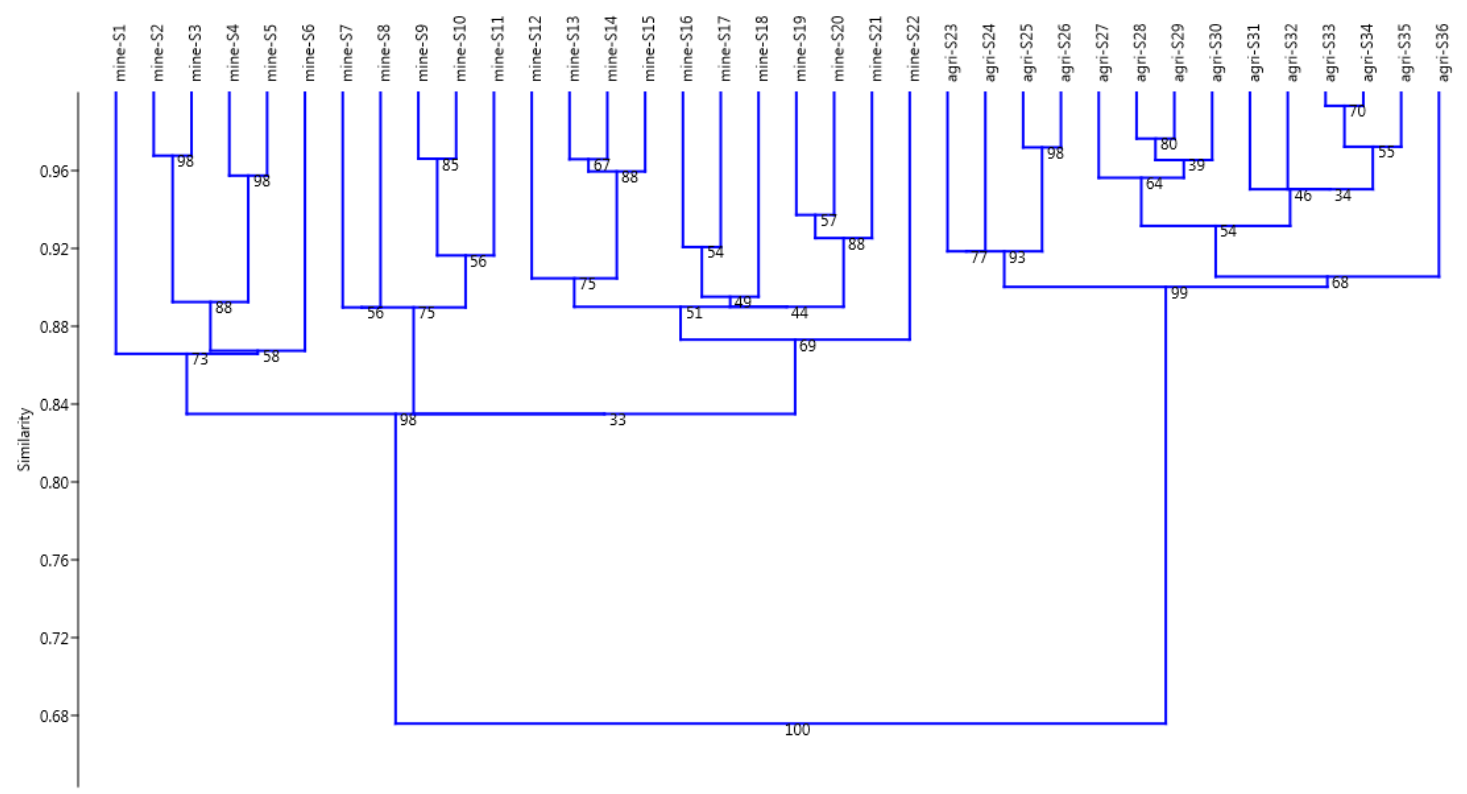

Figure 6. UPGMA cluster analysis of mine and agricultural soil samples

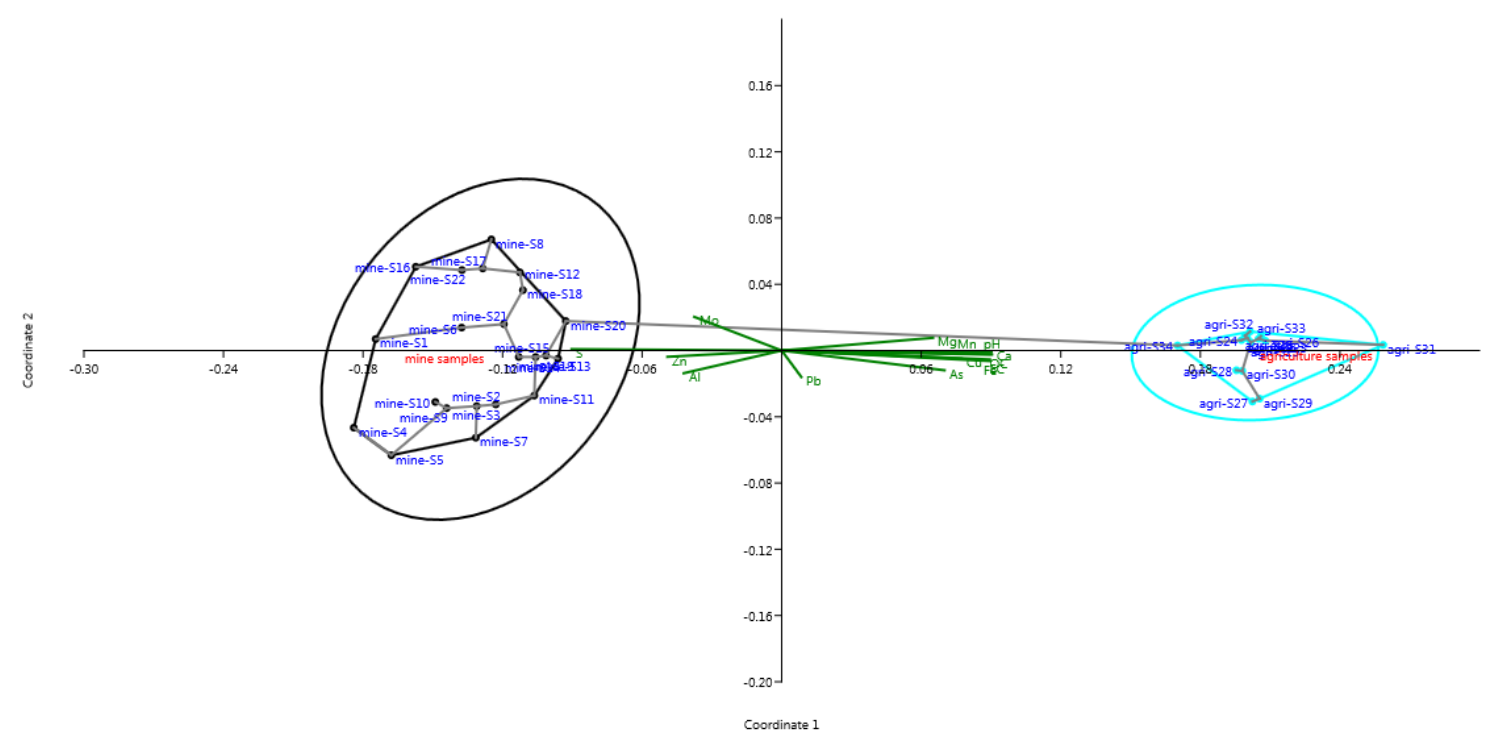

Figure 7. Non-metric multidimensional scaling (N-MDS) of dissimilarities between samples and physicochemical parameters. Mine soil samples (black), agricultural soil samples (blue), and physicochemical parameters ( $\mathrm{Al}, \mathrm{As}, \mathrm{Ca}, \mathrm{Cu}, \mathrm{Mg}, \mathrm{Mn}, \mathrm{Pb}, \mathrm{Zn}, \mathrm{Mo}, \mathrm{S}, \mathrm{Fe}$, and $\mathrm{pH}$ ) (green) 


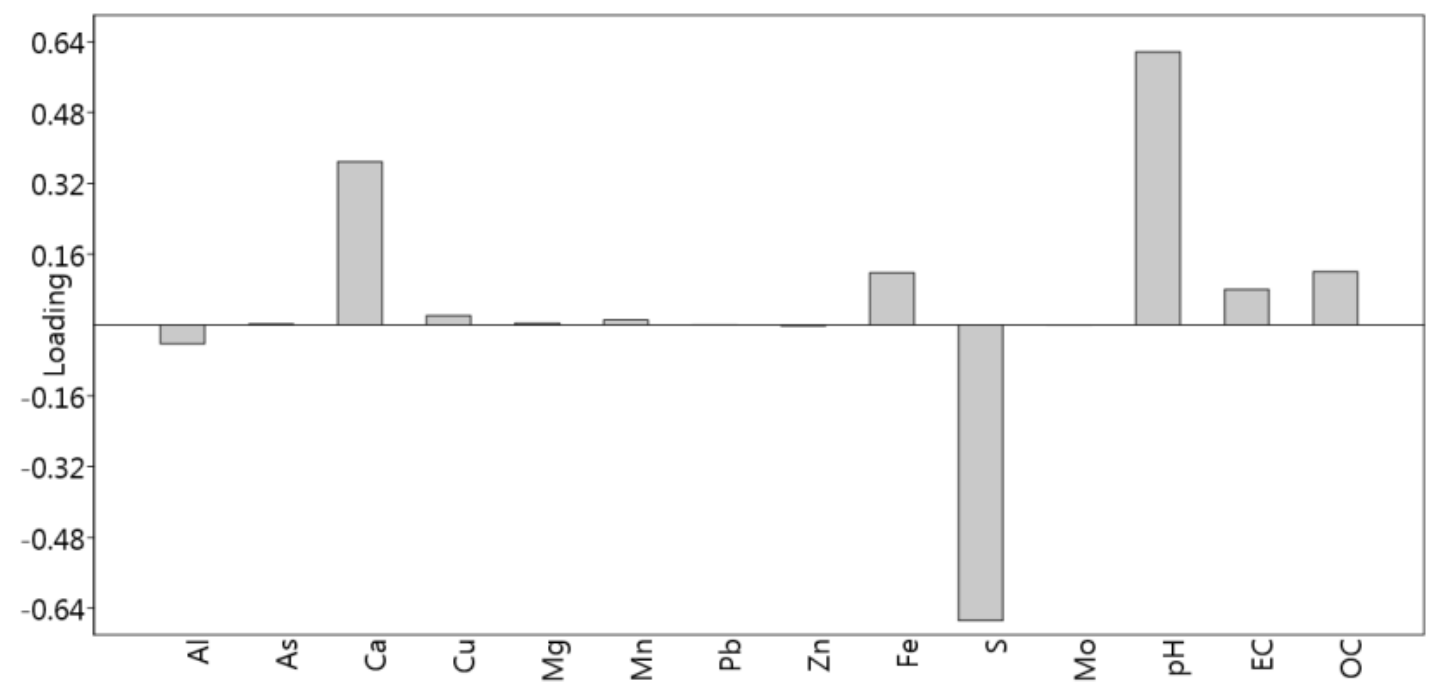

Figure 8. Principal components analysis (PCA) of environmental factors on bacterial communities in mine and agricultural samples

\section{Discussion}

DNA-based bacterial identification techniques (full-length cloning and DGGE screening of the $16 \mathrm{~S}$ rRNA gene) provided successful methods to elucidate the diversity of bacterial populations of the copper mine and the surrounding agricultural area, similar to other studies (Bielefeldt et al., 2009; Blaud et al., 2014; Brito et al., 2013; Gelsomino et al., 1999). The noticeable environmental conditions of the mine and agricultural sites strongly influenced the production of habitat-specific communities of Acidithiobacillus sp. and Sulfobacillus sp. bacteria in the mine area and communities of Thiobacillus sp. and Starkeya sp. in the agricultural area. Detection of facultative sulfur oxidizing bacteria in agriculture soil samples could be due to root exudates of plants (Widawati et al., 2005).

The Gammaproteobacteria class was the main bacterial community in the mine environment, with $63 \%$ abundance at the copper mine and $39 \%$ in the surrounding agricultural area. As is clear from most reported data of copper mine environments (Hao et al., 2007; Heinzel et al., 2009; Rodrigues et al., 2014), bacterial species which belong to Gammaproteobacteria had higher frequency than other bacterial species. Gammaproteobacteria species of At.ferroxidans, At. ferridurans, At. thiooxidans, and At. caldus convert insoluble sulphide to soluble minerals which are frequent in acidic mine soils (Friedrich et al., 2001). In this study these Gammaproteobacteria comprised $7 \%, 13 \%, 1 \%$, and $9 \%$ relative abundance of bacterial communities of the mine environment, respectively, and were not identified in agricultural soil. This could be due to the acidophilic characteristic of these bacterial species, in concordance with Norris (2007), Rojas-Avelizapa et al. (2013), and Rodrigues et al. (2014) (Norris, 2007; Rodrigues et al., 2014; Rojas-Avelizapa et al., 2013).

Heterotrophic Gammaproteobacteria, including Pseudomonas sp., Pseudomonas syringae, and Acinetobacter johnsonii, were isolated from both the mine and 
agricultural environments with $12 \%, 15 \%$, and $8 \%$ at the mine and $11 \%, 24 \%$, and $4 \%$ in agricultural soils, respectively. Since these bacterial species use organic matter as a carbon resource in soil for metabolism (Okibe and Johnson, 2004), colonization conditions are sustained in both mine and agricultural environments. Ac. johnsonii OTU as a heterotroph phosphate reducing bacteria in mine soils had a relative frequency twice that of agricultural soil ( $8 \%$ and $4 \%$, respectively). This could be due to the impact of the overgrowth of other bacterial communities that consequently decreased its relative abundance.

In contrast to the mine soil where Gammaproteobacteria was dominant, in agricultural soil a high abundance of Betaproteobacteria class was detected while none was detected in mine soil samples. Neutrophilic characteristics of these bacteria differentiate them for proliferation in agricultural soil with a $\mathrm{pH}$ of 7 (Chapman, 1990; Widawati et al., 2005). There have been no reports of the existence of Betaproteobacteria in studies of copper mine environments until this study (Norris, 2007; Rodrigues et al., 2014; Sánchez-Andrea et al., 2011).

The Actinobacteria genus relative frequency in agricultural soils was greater than in mine soils, at $10 \%$ and $5 \%$, respectively. This pattern was discovered in studies of Jiang et al. (1991) and Dhanasekaran et al. (2013) that implied a high coordination between organic matter of agricultural soil and the frequency of Actinobacteria (Dhanasekaran et al., 2013; Jiang and Xu, 1990). The Halospirulina sp. OTU as an autotroph and extremophile bacteria was identified solely in mine soil (6\% relative abundance), similar to studies of Rodrigues et al. (2014), Díez et al. (2007), and Hao et al. (2007) (Díez et al., 2007; Hao et al., 2007; Rodrigues et al., 2014).

Clustering analysis of all the above bacterial combinations in mine and agricultural soil samples separates the two sites completely in a UPGMA tree (Figure 5). Significant differences in element concentrations, soil manipulation, water, and organic matter content of mine and surrounding agricultural soils over the long term produce habitatspecific bacterial communities. According to the results of N-MDS analysis, chemical parameters of sulphur, $\mathrm{pH}$, and $\mathrm{Ca}$ have the most effect on a bacterial community's proportion in different soil samples (Figure 7). Rodrigues et al. (2014) addressed the water and organic matter content of soil in a copper mine area as the main parameter of bacterial differentiation between slope and drainage sites (Rodrigues et al., 2014).

\section{Conclusion}

Bacterial communities of a copper mine and the surrounding soil are dependent on different environmental conditions such as element concentration ( $\mathrm{S}, \mathrm{Ca}, \mathrm{Al}, \mathrm{Mg}, \mathrm{Zn}$, $\mathrm{Mn}$, etc.), $\mathrm{pH}$, organic matter, mineralogy, and other climatic properties (temperature, precipitation, evaporation, etc.) and produce habitat-specific communities over a long time period. In this study, relative frequency of SOB in two different soils using culturedependent and independent approach has been investigated. Result indicated that soil samples from a mine site at the Sarcheshmeh Copper Complex contained these diverse genera of sulphur-oxidizing bacteria, including Acidithiobacillus sp. and Sulfobacillus sp. and non-sulphur oxidizing bacteria, including Pseudomonas sp., Bacillus sp., Sphingobium sp., Sphingomonas sp., Acinetobacter sp., Halospirulina sp., and Propionibacterium $s p$. which were derived from the significant effect of sulphur concentrations. In addition, in soil samples from agricultural land surrounding the mine, genera of SOB included Thiobacillus sp., Starkeya sp., and non-SOB genera included 
Pseudomonas sp., Acinetobacter sp., Bacillus sp., Sphingobium sp., Streptomyces sp., and Propionibacterium sp., the presence of which was owing to the significant effect of $\mathrm{pH}$ and calcium concentrations.

Acknowledgments. The authors thank National Iranian Copper Industries Company (Sarcheshmeh Copper Complex) for funding this research. We also thank Prof. Ramon Rossello-Mora (Marine Microbiology Group, IMEDEA (CSIC-UIB), 07190 Esporles, Illes Balears, Spain) for helpful suggestions.

\section{REFERENCES}

[1] Bielefeldt, A., Gutierrez-Padilla, M.G.D., Ovtchinnikov, S., Silverstein, J., Hernandez, M. (2009): Bacterial kinetics of sulfur oxidizing bacteria and their biodeterioration rates of concrete sewer pipe samples. - Journal of Environmental Engineering 136: 731-738.

[2] Blaud, A., Chevallier, T., Virto, I., Pablo, A.-L., Chenu, C., Brauman, A. (2014): Bacterial community structure in soil microaggregates and on particulate organic matter fractions located outside or inside soil macroaggregates. - Pedobiologia 57: 191-194.

[3] Bond, P.L., Smriga, S.P., Banfield, J.F. (2000): Phylogeny of microorganisms populating a thick, subaerial, predominantly lithotrophic biofilm at an extreme acid mine drainage site. - Applied and Environmental Microbiology 66: 3842-3849.

[4] Brito, E.M., Piñón-Castillo, H.A., Guyoneaud, R., Caretta, C.A., Gutiérrez-Corona, J.F., Duran, R., Reyna-López, G.E., Nevárez-Moorillón, G.V., Fahy, A., Goñi-Urriza, M. (2013): Bacterial biodiversity from anthropogenic extreme environments: a hyperalkaline and hyper-saline industrial residue contaminated by chromium and iron. Applied microbiology and biotechnology 97: 369-378.

[5] Brofft, J.E. (2002): Molecular analysis of bacterial communities associated with a forested wetland impacted by reject coal. Diss. University of Georgia.

[6] Castilla, J., Nealler, E. (1978): Marine environmental impact due to mining activities of El Salvador copper mine, Chile. - Marine Pollution Bulletin 9: 67-70.

[7] Chapman, S. (1990): Thiobacillus populations in some agricultural soils. - Soil Biology and Biochemistry 22: 479-482.

[8] Clarke, K.R. (1993): Non-parametric multivariate analyses of changes in community structure. - Australian journal of ecology 18: 117-117.

[9] Cole, J.R., Chai, B., Farris, R.J., Wang, Q., Kulam, S., McGarrell, D.M., Garrity, G.M., Tiedje, J.M. (2005): The Ribosomal Database Project (RDP-II): sequences and tools for high-throughput rRNA analysis. - Nucleic acids research 33: 294-296.

[10] Dhanasekaran, D., Thajuddin, N., Panneerselvam, A. (2013): Distribution and Ecobiology of Antagonistic Streptomyces from Agriculture and Coastal Soil in Tamil Nadu, India.

[11] Díez, B., Bauer, K., Bergman, B. (2007): Epilithic cyanobacterial communities of a marine tropical beach rock (Heron Island, Great Barrier Reef): diversity and diazotrophy. - Applied and environmental microbiology 73: 3656-3668.

[12] Friedrich, C.G., Rother, D., Bardischewsky, F., Quentmeier, A., Fischer, J. (2001): Oxidation of reduced inorganic sulfur compounds by bacteria: emergence of a common mechanism? - Applied and Environmental Microbiology 67: 2873-2882.

[13] Gelsomino, A., Keijzer-Wolters, A.C., Cacco, G., van Elsas, J.D. (1999): Assessment of bacterial community structure in soil by polymerase chain reaction and denaturing gradient gel electrophoresis. - Journal of Microbiological Methods 38: 1-15.

[14] Grundmann, L., Gourbiere, F. (1999): A micro-sampling approach to improve the inventory of bacterial diversity in soil. - Applied Soil Ecology 13: 123-126. 
[15] Hao, C.-b., Zhang, H.-x., Bai, Z.-h., Qing, H., Zhang, B.G. (2007): A novel acidophile community populating waste ore deposits at an acid mine drainage site. - Journal of Environmental Sciences 19: 444-450.

[16] Heinzel, E., Hedrich, S., Janneck, E., Glombitza, F., Seifert, J., Schlömann, M. (2009): Bacterial diversity in a mine water treatment plant. - Applied and environmental microbiology 75: 858-861.

[17] Holt, J., Krieg, N., Sneath, P., Staley, J., Williams, S. (1994): Bergey's manual of determinative microbiology. Williams and Wilkins, Maryland.

[18] Jiang, C., Xu, L. (1990): Characteristics of the populations of soil actinomycetes in Yunnan. - Actinomycetes 1: 67-74.

[19] Johnson, D. (2008): Biodiversity and interactions of acidophiles: Key to understanding and optimizing microbial processing of ores and concentrates. - Transactions of Nonferrous Metals Society of China 18: 1367-1373.

[20] Kelly, D.P., Wood, A.P. (2000): Reclassification of some species of Thiobacillus to the newly designated genera Acidithiobacillus gen. nov., Halothiobacillus gen. nov. and Thermithiobacillus gen. nov. - International Journal of Systematic and Evolutionary Microbiology 50(2): 511-516.

[21] Marsh, R.M., Norris, P.R. (1983): The isolation of some thermophilic, autotrophic, ironand sulfur-oxidizing bacteria. - FEMS Microbiology Letters 17: 311-315.

[22] Mendez, M.O., Neilson, J.W., Maier, R.M. (2008): Characterization of a bacterial community in an abandoned semiarid lead-zinc mine tailing site. - Applied and environmental microbiology 74: 3899-3907.

[23] Muyzer, G., Smalla, K. (1998): Application of denaturing gradient gel electrophoresis (DGGE) and temperature gradient gel electrophoresis (TGGE) in microbial ecology. Antonie van Leeuwenhoek 73: 127-141.

[24] Norris, P.R. (2007): Acidophile diversity in mineral sulfide oxidation. - Biomining. Springer 199-216.

[25] Okibe, N., Johnson, D.B. (2004): Biooxidation of pyrite by defined mixed cultures of moderately thermophilic acidophiles in $\mathrm{pH}$-controlled bioreactors: Significance of microbial interactions. - Biotechnology and bioengineering 87: 574-583.

[26] Ranjard, L., Lejon, D.P., Mougel, C., Schehrer, L., Merdinoglu, D., Chaussod, R. (2003): Sampling strategy in molecular microbial ecology: influence of soil sample size on DNA fingerprinting analysis of fungal and bacterial communities. - Environmental Microbiology 5: 1111-1120.

[27] Rodrigues, V.D., Torres, T.T., Ottoboni, L.M. (2014): Bacterial diversity assessment in soil of an active Brazilian copper mine using high-throughput sequencing of 16S rDNA amplicons. - Antonie van Leeuwenhoek 106: 879-890.

[28] Rojas-Avelizapa, N., Gómez-Ramírez, M., Hernández-Gama, R., Aburto, J., García de León, R. (2013): Isolation and selection of sulfur-oxidizing bacteria for the treatment of sulfur-containing hazardous wastes. - Chemical and Biochemical Engineering Quarterly 27: 109-117.

[29] Sánchez-Andrea, I., Rodríguez, N., Amils, R., Sanz, J.L. (2011): Microbial diversity in anaerobic sediments at Rio Tinto, a naturally acidic environment with a high heavy metal content. - Applied and environmental microbiology 77: 6085-6093.

[30] Schoenborn, L., Yates, P.S., Grinton, B.E., Hugenholtz, P., Janssen, P.H. (2004): Liquid serial dilution is inferior to solid media for isolation of cultures representative of the phylum-level diversity of soil bacteria. - Applied and environmental microbiology 70: 4363-4366.

[31] Schultz, L.G. (1964): Quantitative interpretation of mineralogical composition from Xray and chemical data for the Pierre Shale - United States GovernmentPrinting Office, Washington 
[32] Smith, F.W., Rae, A.L., Hawkesford, M.J. (2000): Molecular mechanisms of phosphate and sulphate transport in plants. Biochimica et Biophysica Acta (BBA). - Biomembranes 1465: 236-245.

[33] Soil Survey Staff (2010): Keys to Soil Taxonomy, 11th ed. USDA-Natural Resources Conservation Service, Washington, DC

[34] Sorokin, D.Y., Tourova, T.P., Lysenko, A.M., Muyzer, G. (2006): Diversity of culturable halophilic sulfur-oxidizing bacteria in hypersaline habitats. - Microbiology 152: 30133023.

[35] Stackebrandt, E., Frederiksen, W., Garrity, G.M., Grimont, P.A., Kämpfer, P., Maiden, M.C., Nesme, X., Rosselló-Mora, R., Swings, J., Trüper, H.G. (2002): Report of the ad hoc committee for the re-evaluation of the species definition in bacteriology. International journal of systematic and evolutionary microbiology 52: 1043-1047.

[36] Walkley, A., Black, I.A. (1934): An examination of the Degtjareff method for determining soil organic matter, and a proposed modification of the chromic acid titration method. - Soil science 37: 29-38.

[37] Widawati, S., Suliasih, H.L., Sugiharto, A. (2005): Biodiversity of Soil Microbes from Rhizosphere at Wamena Biological Garden (WBiG), Jayawijaya, Papua. - Biodiversitas 6: 6-11.

[38] Ying, T., Yong-Ming, L., HUANG, C.-Y., Jian, L., Zhen-Gao, L., Christie, P. (2008): Tolerance of grasses to heavy metals and microbial functional diversity in soils contaminated with copper mine tailings. - Pedosphere 18: 363-370.

[39] Yun-Guo, L., Zhang, H.-Z., Guang-Ming, Z., Huang, B.-R., Xin, L. (2006): Heavy metal accumulation in plants on Mn mine tailings. - Pedosphere 16: 131-136. 